\title{
PEMETAAN KUALITAS MADRASAH ALIYAH \\ DI KABUPATEN KUTAI KARTANEGARA PROVINSI KALIMANTAN TIMUR
}

Amiruddin*

Balai Peneitian dan Pengembangan Agama Makassar Jl. AP.Pettarani No. 72 Makassar Email: amiruddinlaterru@gmail.com INFO ARTIKEL ABSTRAK

Tujuan penelitian ini berusaha untuk memotret kondisi objektif Tingkat kualitas madrasah aliyah negeri dan swasta di Kabupaten Kutai Kartanegara Provinsi Kalimantan Timur. Metode Pendekatan yang digunakan adalah kuantitatif dengan analisis statistik deskriptif eksploratif melalui angket/kuesioner dan pengamatan secara langsung terhadap implementasi delapan (8) SNP (Standar Nasional Pendidikan). Masalah penelitian adalah "Bagaimana Tingkat kualitas Madrasah Aliyah di Kabupaten Kutai terhadap delapan (8) Standar Nasional Pendidikan”. Teknik pengumpulan data dilakukan dengan mengedarkan angket/kuesioner kepada informan kunci yang meliputi Kepala Madrasah, Wakil Kepala Madrasah, Kepala Tata Usaha, dan beberapa pendidik. Selain itu dilakukan pula wawancara, dan penelusuran dokumen administrasi madrasah. Temuan hasil penelitian ini menyimpulkan bahwa kualitas Madrasah Aliyah di Kabupaten Kutai Kartanegara yang berjumlah 16 Madrasah secara umum capaian kualitasnya 75\% (kategori tinggi) terhadap Standar Nasional Pendidikan. Secara rinci pencapaian kualitas madrasah untuk tipologi MAN 86\% (terkategori sangat tinggi), MAS Non Pesantren yang di kelola oleh yayasan dengan persentase pencapaian $72 \%$ (terkategori tinggi) dan MAS Pesantren yang dikelola oleh Pondok Pesantren pencapaian kualitas sebesar 77\% (terkategori tinggi).

Madrasah Aliyah

\author{
Keywords: \\ Mapping, Madrasah \\ Quality, National \\ Education \\ Standards, \\ Madrasah Aliyah
}

\begin{abstract}
The purpose of this study is to try to capture the objective conditions of the quality of public and private madrasas in the Kutai Kartanegara Regency, East Kalimantan Province. Method The approach used is quantitative with descriptive exploratory statistical analysis through a questionnaire / questionnaire and direct observation of the implementation of eight (8) SNP (National Education Standards). The research problem is "What is the quality level of Madrasah Aliyah in Kutai District with eight (8) National Education Standards". Data collection techniques were carried out by distributing questionnaires / questionnaires to key informants which included the Head of Madrasah, Deputy Head of Madrasah, Head of Administration, and several educators. In addition, interviews were also carried out, and search of madrasa administration documents. The findings of this study conclude that the quality of Aliyah Madrasahs in Kutai Kartanegara District, amounting to 16 Madrasas, generally achieved 75\% quality (high category) against the National Education Standards. In detail the achievement of madrasa quality for typology MAN $86 \%$ (categorized very high), MAS Non Pesantren managed by foundations with $72 \%$ achievement percentage (high categorized) and MAS Pesantren managed by Pondok Pesantren achieving 77\% quality (high categorized) .
\end{abstract}

\section{PENDAHULUAN}

Madrasah merupakan lembaga pendidikan yang ditangani langsung oleh Kementerian agama dan termaktub dalam Undang-Undang Sistim Pendidikan Nasional No. 20 Tahun 2003 merupakan Lembaga Pendidikan bercirikan Islam dimana porsi pembelajaran agama Islamnya jauh lebih banyak dibanding dengan sekolah umum lainnya, diharapkan menghasilkan peserta didik yang berkualitas dan memiliki spiritual 
keagamaan yang mumpuni, serta berakhlak mulia. (Sisdiknas Nomor 20 Tahun 2003).

Pembangunan di bidang pendidikan sampai saat ini masih menjadi prioritas utama dalam upaya meningkatkan kualitas sumber daya manusia (SDM). Pendidikan menjadi barometer kemajuan suatu bangsa, oleh karena itu. kebijakan pemerintah dalam hal pendidikan mengacu kepada suatu upaya strategi pencapaian tujuan pendidikan nasional. (Sarjilah.http://ipmpjogja.diknas.go.id./mat eri/wi/sarjilah/karyatulismaknapmtakehom .pdf,hlm.2).

Salah satu misi Kementerian Agama periode Pembangunan 2014-2019 yang bersentuhan dengan peningkatan kualitas pendidikan agama dan keagamaan adalah: Meningkatkan akses dan kualitas pendidikan umum berciri agama, pendidikan agama pada satuan pendidikan umum, dan pendidikan keagamaan. Berdasarkan misi yang telah dirumuskan oleh Kementerian Agama tersebut diatas, maka Misi yang diemban oleh Kementerian Agama RI di bidang Pendidikan Agama dan keagamaan adalah "Meningkatkan akses dan kualitas pendidikan umum berciri agama, pendidikan agama pada satuan pendidikan umum, dan pendidikan keagamaan. (Misi Kementerian Agama 2014-2019).

Pada tahun 2013, Direktorat Pendidikan Agama Islam telah melaksanakan kegiatan prioritas antara lain, adalah Pengembangan dan Pembinaan Pendidikan Agama dan Pendidikan Keagamaan (PAIS); peningkatan kualitas sejumlah 17.500 guru agama Islam; memberikan bantuan peningkatan kualifikasi S1 kepada sejumlah 1.000 guru PAI dan S2 kepada sejumlah 580 orang guru; memberikan beasiswa S1 kepada sejumlah 3.252 orang guru dan S2 kepada sejumlah 100 orang guru (peserta baru). Direktorat Madrasah telah melaksanakan kegiatan prioritas, antara lain: merehabilitasi sejumlah 1.132 ruang kelas MIS, MTs, dan MA, memberikan bantuan pengelolaan kepada RA kepada 100 lokasi, memberikan bantuan pembangunan RKB sejumlah 327 MI, MTs, dan MA, memberikan bantuan peningkatan mutu kepada sejumlah 320 MI dan MTs, memberikan bantuan pembangunan gedung melalui MEDP kepada sejumlah 250 MI, MTs, dan MA; membangun perpustakaan di sejumlah 65 MI dan MA, mengadakan sarana perpustakaan ke sejumlah $200 \mathrm{MI}$ dan MTs; membangun laboratorium di sejumlah 65 MTs dan MA, mengadakan alat laboratorium di sejumlah 315 MTs dan MA, memberikan bantuan operasional manajemen mutu, pengembangan keterampilan, kepada sejumlah 4.546 madrasah, memberikan beasiswa kepada sejumlah 7500 orang siswa MTs dan MA, memberikan bantuan sertifikasi kepada sejumlah 40.400 guru dan pengawas, memberikan beasiswa dan bantuan peningkatan kualifikasi S1 kepada 6.682 guru madrasah, dan kegiatan peningkatan kompetensi guru, kepala madrasah dan pengawas sejumlah 14.560 orang. (Situs Kementerian Agama RI: 2013).

Pada tahun 2014 antara lain kegiatannya adalah Peningkatan Kualitas Pendidikan Agama di Sekolah sejumlah 34 paket kegiatan dan Penguatan Pembelajaran Bahasa Arab di Sekolah. Direktorat Madrasah telah melaksanakan kegiatan prioritas antara lain membangun sejumlah 500 RKB MI, MTs dan MA; merehabilitasi sejumlah 12.521 ruang kelas MI, MTs, dan MA; membangun sejumlah 150 ruang perpustakaan MI, melaksanakan sejumlah 67 paket peningkatan mutu madrasah dan peningkatan manajemen mutu madrasah di 4.399 lokasi; mengadakan alat peraga matematika 220 paket dan alat pembelajaran multimedia 300 set; membangun laboratorium di sejumlah 450 ruang di MTs dan MA, mengadakan sejumlah 1.100 set alat laboratorium bahasa, IPA, dan komputer di MTs dan MA, membangun 5 paket asrama MTs, mengadakan 3.200 paket buku wajib dan referensi perpustakaan MA, memberikan tunjangan profesi kepada sejumlah 452.316 orang guru, memberikan beasiswa 
peningkatan kualifikasi S1 dan S2 kepada sejumlah 19.134 orang guru, mensertifikasi guru melalui jalur pendidikan sejumlah 2.400 orang guru, menyalurkan dana BOS kepada sejumlah 5.879.297 siswa, memberikan beasiswa kepada 1.750 .000 siswa miskin berprestasi MI, MTs dan MA, memberikan beasiswa pada sejumlah 180.000 siswa RA dan MI di daerah tertinggal, terpencil, perbatasan, dan kepulauan, memberikan bantuan beasiswa berbakat dan berprestasi kepada sejumlah 2.500 siswa MTs dan MA, dan memagangkan sejumlah 5.000 siswa. (Situs Kementerian Agama RI: 2014).

Kondisi real yang dimaksud di atas tidak hanya berkaitan dengan potensi dan permasalahan pendidikan agama dan pendidikan agama sebagai tujuan pemetaan, tetapi juga berkaitan dengan nilai-nilai dan praktik-praktik sosial dalam masyarakat. Ini berarti kebijakan pendidikan agama dan pendidikan tidak boleh bertentangan dengan nilai-nilai dan paktik-praktik sosial yang ada dalam masyarakat. Ketika kebijakan tersebut tidak berisi nilai-nilai yang hidup dalam masyarakat, maka kebijakan publik tersebut akan mendapat resistensi ketika diimplementasikan. Sebaliknya, kebijakan pendidikan agama dan pendidikan keagamaan harus mampu mengakomodasi nilai-nilai dan praktikpraktik yang hidup dan berkembang dalam masyarakat. (Riat Nugroho D:2006).

Karenanya penelitian pemetaan pendidikan agama dan keagamaan menjadi urgen dilakukan untuk memberikan data atau informasi kepada pemerintah dalam menyusun dan menetapkan kebijakan berikutnya. Kebijakan yang diambil nantinya diharapkan mendapat respons positif bagi masyarakat dan selanjutnya memberikan peluang bagi bagi masyarakat untuk berpartisipasi terhadap pembangunan di bidang pendidikan agama dan pendidikan keagamaan. Prinsip utama penelitian pemetaan, adalah mengumpulkan informasi sebanyak mungkin dalam suatu wilayah tertentu secara spesifik yang dapat digunakan sebagai bahan membuat suatu keputusan/kebijakan terbaik. Secara metodologi penelitian pemetaan tidak hanya bertujuan untuk mengungkap informasi berkaitan dengan objek penelitian, tetapi juga menuntut untuk mengungkap data dan informasi mengenai masyarakat termasuk di dalamnya profil dan masalah sosial yang ada pada masyarakat tersebut.

Berdasarkan latar belakang di atas, maka penelitian ini urgen dilakukan untuk mengamati kondisi objektif kualitas madrasah Aliyah di Kabupaten Kutai Kartanegara dengan menelusuri secara mendalam implementasi delapan standar Nasional Pendidikan.

Penelitian ini bertujuan untuk: Menemukan kualitas madrasah di Kabupaten Kutai Kartanegara Provinsi Kalimantan Timur. Kualitas madrasah yang dimaksud berdasarkan delapan (8) aspek Standar Nasional Pendidikan, yaitu: kualitas kurikulum (isi), proses pembelajaran, lulusan, pendidik dan tenaga kependidikan, sarana dan prasarana, pengelolaan, pembiayaan, dan penilaian madrasah.

\section{TINJAUAN TEORETIS Standar Nasionlal Pendidikan}

Implementasi Undang-Undang Nomor 20 tahun 2003 tentang Sistem Pendidikan Nasional dijabarkan ke dalam sejumlah peraturan antara lain Peraturan Pemerintah Nomor 19 Tahun 2005 tentang Standar Nasional Pendidikan. Peraturan Pemerintah ini memberikan arahan tentang perlunya dilaksanakan delapan standar nasional pendidikan, yaitu: standar isi, standar proses, standar kompetensi lulusan, standar pendidik dan tenaga kependidikan, standar sarana dan prasarana, standar pengelolaan, standar pembiayaan, dan standar penilaian pendidikan. (PP. No. 19 Tahun 2005).

\section{Isi (Kurikulum)}

Dokumen standar isi (sesuai Lampiran Peraturan Menteri Pendidikan Nasional Nomor 22 Tahun 2006 Tanggal 23 
Mei 2006 Standar Isi) yang secara keseluruhan mencakup: a) Kerangka dasar dan struktur kurikulum yang merupakan pedoman dalam penyusunan kurikulum pada tingkat satuan pendidikan; b) Beban belajar bagi peserta didik pada satuan pendidikan dasar dan menengah; c) Kurikulum tingkat satuan pendidikan yang akan dikembangkan oleh satuan pendidikan berdasarkan panduan penyusunan kurikulum sebagai bagian tidak terpisahkan dari standar isi, dan d) Kalender pendidikan untuk penyelenggaraan pendidikan pada satuan pendidikan jenjang pendidikan dasar dan menengah. Untuk lebih jelasnya dan detail nya dapat dibaca lampiran regulasi tersebut.

\section{Standar Proses Pendidikan}

Standar proses adalah standar nasional pendidikan yang berkaitan dengan pelaksanaan pembelajaran pada satuan pendidikan untuk mencapai kompetensi lulusan. Standar proses berisi kriteria minimal proses pembelajaran pada satuan pendidikan dasar dan menengah di seluruh wilayah hukum Negara Kesatuan Republik Indonesia. Standar proses ini berlaku untuk jenjang pendidikan dasar dan menengah pada jalur formal, baik pada sistem paket maupun pada sistem kredit semester.

Dalam Lampiran Peraturan Menteri Pendidikan Nasional Nomor 41 Tahun 2007 Tanggal 23 November 2007 tentang Standar Proses Untuk Satuan Pendidikan Dasar Dan Menengah dinyatakan bahwa standar proses pendidikan meliputi perencanaan proses pembelajaran, pelaksanaan proses pembelajaran, penilaian hasil pembelajaran, dan pengawasan proses pembelajaran untuk terlaksananya proses pembelajaran yang efektif dan efisien.

\section{Standar Kompetensi Lulusan}

Standar Kompetensi Lulusan Satuan Pendidikan (SKL-SP) berdasarkan Lampiran Peraturan Menteri Pendidikan Nasional Nomor 23 Tahun 2006 Tanggal 23 Mei 2006 Standar Kompetensi Lulusan (SKL) meliputi: 1) SD/MI/SDLB/Paket A, $\begin{array}{lll}\text { SMP/MTs/SMPLB/Paket } & \text { B, } & 3 \text { ) } \\ \text { SMA/MA/SMALB/Paket } & \text { C, } & 4)\end{array}$ SMK/MAK.

Standar Kompetensi Lulusan Satuan Pendidikan (SKL-SP) dikembangkan berdasarkan tujuan setiap satuan pendidikan, yakni: 1. Pendidikan Dasar, yang meliputi SD/MI/SDLB/Paket A dan SMP/MTs/SMPLB/Paket B bertujuan: Meletakkan dasar kecerdasan, pengetahuan, kepribadian, akhlak mulia, serta keterampilan untuk hidup mandiri dan mengikuti pendidikan lebih lanjut; 2. Pendidikan Menengah yang terdiri atas SMA/MA/SMALB/Paket C bertujuan: Meningkatkan kecerdasan, pengetahuan, kepribadian, akhlak mulia, serta keterampilan untuk hidup mandiri dan mengikuti pendidikan lebih lanjut; 3 . Pendidikan Menengah Kejuruan yang terdiri atas SMK/MAK bertujuan: Meningkatkan kecerdasan, pengetahuan, kepribadian, akhlak mulia, serta keterampilan untuk hidup mandiri dan mengikuti pendidikan lebih lanjut sesuai dengan kejuruan nya. Lebih jelasnya dapat dibaca pada regulasi lampiran regulasi dimaksud.

\section{Standar Tenaga Pendidik dan Kependidikan}

Tenaga pendidik dan tenaga kependidikan mencakup, guru, konselor, kepala sekolah, tenaga administrasi, tenaga perpustakaan, tenaga laboratorium, dan tenaga layanan khusus. Sejumlah regulasi yang telah mengatur standar kompetensi pendidik dan tenaga kependidikan tersebut yaitu kompetensi guru diatur dalam Peraturan Menteri Pendidikan Nasional Nomor 16 Tahun 2007 Tanggal 4 Mei 2007 Tentang Standar Kualifikasi Akademik Dan Kompetensi Guru; kompetensi Konselor diatur dalam Peraturan Menteri Pendidikan Nasional Republik Indonesia Nomor 27 Tahun 2008 Tentang Standar Kualifikasi Akademik Dan Kompetensi Konselor; kompetensi kepala sekolah/madrasah diatur dalam Peraturan Menteri Pendidikan Nasional Nomor 13 Tahun 2007 Tanggal 17 
April 2007 Tentang Standar Kepala Sekolah/Madrasah; dan kompetensi pengawas pendidikan diatur dalam Peraturan Menteri Pendidikan Nasional Republik Indonesia Nomor 12 Tahun 2007 Tentang Standar Pengawas Sekolah/Madrasah.

\section{Standar Sarana dan Prasarana}

Berdasarkan Lampiran Peraturan Menteri Pendidikan Nasional Nomor 24 Tahun 2007 Tanggal 28 Juni 2007 Standar Sarana dan Prasarana Untuk Sekolah Dasar/Madrasah Ibtidaiyah (SD/MI), Sekolah Menengah Pertama/Madrasah Tsanawiyah (SMP/MTs), Dan Sekolah Menengah Atas/Madrasah Aliyah (SMA/MA), dinyatakan cakupan standar sarana dan prasarana satuan pendidikan meliputi: Satuan Pendidikan, Lahan, Bangunan Gedung, dan Kelengkapan Prasarana dan Sarana.

\section{Standar Pengelolaan Pendidikan}

Standar pengelolaan pendidikan oleh satuan pendidikan merujuk pada Lampiran Peraturan Menteri Pendidikan Nasional Nomor 19 Tahun 2007 Tanggal 23 Mei 2007 tentang Standar Pengelolaan Pendidikan Oleh Satuan Pendidikan Dasar dan Menengah. Standar pengelolaan satuan pendidikan dalam regulasi tersebut mencakup: Perencanaan Program, Pelaksanaan Rencana Kerja, Pengawasan dan Evaluasi, Kepemimpinan Sekolah/Madrasah, Sistem Informasi Manajemen, dan Penilaian Khusus.

\section{Standar Pembiayaan Pendidikan}

Peraturan Menteri Pendidikan Nasional Nomor 69 Tahun 2009 Tentang Standar Biaya Operasi Non personalia Tahun 2009 Untuk Sekolah Dasar/Madrasah Ibtidaiyah (SD/MI), Sekolah Menengah Pertama/Madrasah Tsanawiyah (SMP/MTs), Sekolah Menengah Atas/Madrasah Aliyah (SMAMA), Sekolah Menengah Kejuruan (SMK), Sekolah Dasar Luar Biasa (SDLB), Sekolah Menengah Pertama Luar Biasa
(SMPLB), dan Sekolah Menengah Atas Luar Biasa (SMALB). Regulasi tersebut mencakup Ketentuan jumlah rombongan belajar per sekolah/program keahlian dan jumlah peserta didik per rombongan belajar untuk perhitungan biaya operasi non personalia, dan Standar Biaya Operasi Non personalia per Sekolah/Program Keahlian,per Rombongan Belajar, dan per Peserta Didik untuk SD/MI, SMP/MTs, SMA/MA, SDLB, SMPLB, SMALB, dan SMK di DKI Jakarta pada tahun 2009.

\section{Standar Penilaian Pendidikan}

\section{Lampiran Peraturan Menteri}

Pendidikan Nasional Nomor 20 Tahun 2007

Tanggal 11 Juni 2007 Standar Penilaian Pendidikan. Regulasi tersebut mengatur standar penilaian pendidikan yang mencakup: Pengertian Penilaian, Prinsip Penilaian, Teknik dan Instrumen Penilaian, Mekanisme dan Prosedur Penilaian, Penilaian oleh Pendidik, Penilaian oleh Satuan Pendidikan, dan Penilaian oleh Pemerintah.

\section{Penelitian Pemetaan}

Priadi Surya dalam disertasinya telah mengembangkan konsep pemetaan pendidikan dari konsep pemetaan sekolah. Berbagai aspek pendidikan dalam ruang lingkup sekolah dibawa ke ranah yang lebih luas. Baik dalam hal ruang lingkup kajian maupun luasan wilayah yang dibahas. Pemetaan pendidikan ini mengadopsi dan mengadaptasi konsep pemetaan dari ilmu geografi. Peta sebagai salah satu bidang kajian geografi digunakan sebagai sarana untuk mengetahui persebaran sesuatu hal dalam bidang pendidikan. Geografi yang dimaksud pun dapat berupa geografi fisik maupun sosial (non fisik). Geografi fisik dapat digunakan dalam keperluan sistem fasilitas pendidikan. Sistem fasilitas pendidikan bertujuan untuk menyediakan lingkungan fisik yang dapat membantu tercapainya keberhasilan individu dalam proses pembelajaran. Hal ini contohnya dapat digunakan ketika kita hendak 
menentukan lokasi pendirian sekolah. Priadisurya@Uny.Ac.Id

Geografi sosial dapat digunakan dalam keperluan sistem aktivitas pendidikan, sistem komunikasi pendidikan, dan sistem operasional pendidikan menggunakan geografi sosial seperti yang dikembangkan oleh Gatot Hermanto (2008:6-7). Contohnya seperti pemetaan tenaga pendidik di suatu wilayah. Terdapat konsep esensial dan prinsip geografi yang dapat digunakan sebagai acuan dalam pemetaan pendidikan. Geografi pada hakikatnya merupakan studi tentang gejalagejala yang nyata dalam kehidupan manusia. Gejala geografi yang ada di sekitar kita merupakan hasil keseluruhan interelasi keruangan antara faktor fisis dan non fisis. Dalam mempelajari geografi terdapat pola nyata dan abstrak. Pola abstrak dalam bentuk pengertian abstraksi disebut konsep. Konsep esensial geografi meliputi konsep lokasi, konsep jarak, konsep keterjangkauan, konsep pola, konsep morfologi, konsep aglomerasi, konsep nilai kegunaan, konsep interaksi, konsep diferensiasi areal, dan konsep keterkaitan ruangan. Adapun prinsip geografi merupakan dasar mengkaji dan mengungkapkan gejala masalah geografi di permukaan bumi. Secara teoretis prinsip geografi terdiri dari prinsip penyebaran, prinsip interelasi, prinsip deskripsi, dan prinsip kronologi. (Gatot Harmanto. 2008:6-7).

\section{METODE PENELITIAN}

Penelitian ini adalah penelitian pemetaan yang menggunakan pendekatan Kuantitatif Deskriptif Eksploratif pada Madrasah Aliyah di Kutai Kartanegara terhadap delapan komponen Standar Pendidikan Nasional. Penelitian ini dilaksanakan di Kabupaten Kutai Kartanegara. Sedangkan sasaran penelitian adalah seluruh satuan pendidikan agama tingkat menengah atau Madarasah Aliyah di Kabupaten Kutai Kartanegara.

Jenis data dalam penelitian ini terdiri atas dua macam, yaitu data kuantitatif dan data kualitatif. Data kuantitatif mencakup, nominal, interval, ordinal maupun rasio yang berkaitan dengan delapan komponen pendidikan (Standar Nasional Pendidikan), sementara data kualitatif berkaitan dengan kondisi fisik, sosial, budaya, dan keamanan lingkungan madrasah. Sementara kualitas madrasah yang dimaksud adalah delapan standar komponen satuan pendidikan, yaitu kurikulum, lulusan, Pendidik dan tenaga kependidikan, sarana dan prasarana, proses pendidikan, pengelolaan, pembiayaan dan evaluasi.

Sumber data terdiri dari dua sumber yaitu data primer dan data sekunder. Data primer akan diperoleh pada madrasah aliyah yang menjadi sampel. Di setiap madrasah ditentukan sejumlah enam orang responden, yaitu, kepala madrasah, wakil kepala madrasah bidang kurikulum, sarana dan prasarana, kesiswaan, kepala tata usaha dan bendahara madrasah. Sementara data sekunder akan diperoleh dari dari instansi penyedia data terkait, seperti Kantor Kementerian Agama setempat, baik tingkat Provinsi maupun Kabupaten/Kota, BPS setempat, perpustakaan nasional dan perguruan tinggi setempat, dan lain-lain.

Instrumen penelitian terdiri atas dua yaitu angket dan pedoman wawancara. Angket digunakan untuk menjaring data kuantitatif sesuai dengan yang dijelaskan pada bagian jenis data terdahulu. Untuk menjamin validitas dan reliabilitas maka instrumen yang digunakan dalam penelitian ini adalah instrumen akreditasi SMU/MA yang telah disusun oleh tim akreditasi nasional. Dalam angka menyesuaikan dengan tujuan penelitian maka revisi teknis penataan dilakukan tanpa merubah substansi instrumen. Sementara pedoman wawancara digunakan untuk menjaring data kualitatif.

Populasi penelitian adalah seluruh Madrasah Aliyah di Kabupaten Kutai Kartanegara. Penarikan sampel dilakukan dengan cara purposive sampling berdasarkan kabupaten/kota. Tahap pertama adalah menentukan sampel dengan menggunakan Formula Nomogram Herry 
King pada taraf signifikansi 5\%. Tahap kedua adalah menentukan jumlah sampel setiap kabupaten/kota secara proporsi. Pengolahan dan analisis data dilakukan dengan empat proses yaitu: a) Input Data. b) Manajemen Data, c) Analisis dan, d) Penayangan grafis dan visualisasi.

\section{TEMUAN PENELITIAN}

Sebagaimana telah diungkapkan sebelumnya bahwa jumlah madrasah aliyah yang menjadi sasaran penelitian ini sebanyak 16 buah madrasah yang tersebar pada 11 Kecamatan, ini berarti masih terdapat 7 Kecamatan yang tidak memiliki madrasah aliyah baik negeri maupun swasta.

Kondisi madrasah menurut penuturan Kasi Madrasah sudah lumayan memadai hal ini ditandai dengan semua madrasah tersebut sudah terakreditasi. Terdapat 5 madrasah yang memiliki tingkat akreditasi A yaitu, MAN Tenggarong, MAN Kota Bangun, MAS Nuruddin Samboja, MAS Miftahul Ulum Anggana, MAS PPKP Ribathul Khail Tenggarong. Sedangkan madrasah yang memperoleh akreditasi B sebanyak 11 buah, yaitu; MAS Al Mu'minun Muara Muntai, MAS Al Mukarramah Muara Jawa, MAS Nahdlatul Wathan Tenggarong Seberang, MAS Al Masyhuriyah Tenggarong Seberang, MAS
Hidayatul Mubtadin Muara Kaman, MAS DDI Karya Baru Loa Janan, MAS Al Ikhsan Tenggarong Seberang, MAS As'adiyah Santan Tengah, MAS Bahrul Ulum Kenohan, MAS Darul Ihsan Anggana, dan MAS Ibadurrahman Tenggarong Seberang.

\section{Kualitas Madrasah Aliyah di Kabupaten Kutai Kartanegara berdasarkan Standar Nasional Pendidikan (SNP)}

Mengukur tingkat kualitas madrasah aliyah terhadap delapan (8) komponen Standar Nasional Pendidikan yang telah di lakukan oleh Badan Akreditasi Nasional SMA/Madrasah (BAN-SMU/MA) yang meliputi; 1). Standar Isi (Kurikulum), 2). Lulusan, 3). Proses Pendidikan, 4). Tenaga Pendidik dan Kependidikan, 5). Sarana dan Prasarana, 6). Pengelolaan, 7). Pembiayaan, dan 8). Evaluasi.

Secara umum, berdasarkan hasil analisis data kuesioner terhadap 16 madrasah aliyah yang ada di Kabupaten Kutai Kartanegara menunjukkan bahwa pencapaian tingkat kualitas yang dimiliki terkategori "Tinggi" dari standar nasional pendidkan dengan persentase $75,4 \%$, ini berarti masih terdapat sebanyak $24,6 \%$ tingkat ketercapaian belum terpenuhi. Untuk lebih jelasnya dapat diamati pada grafik 1 berikut ini:

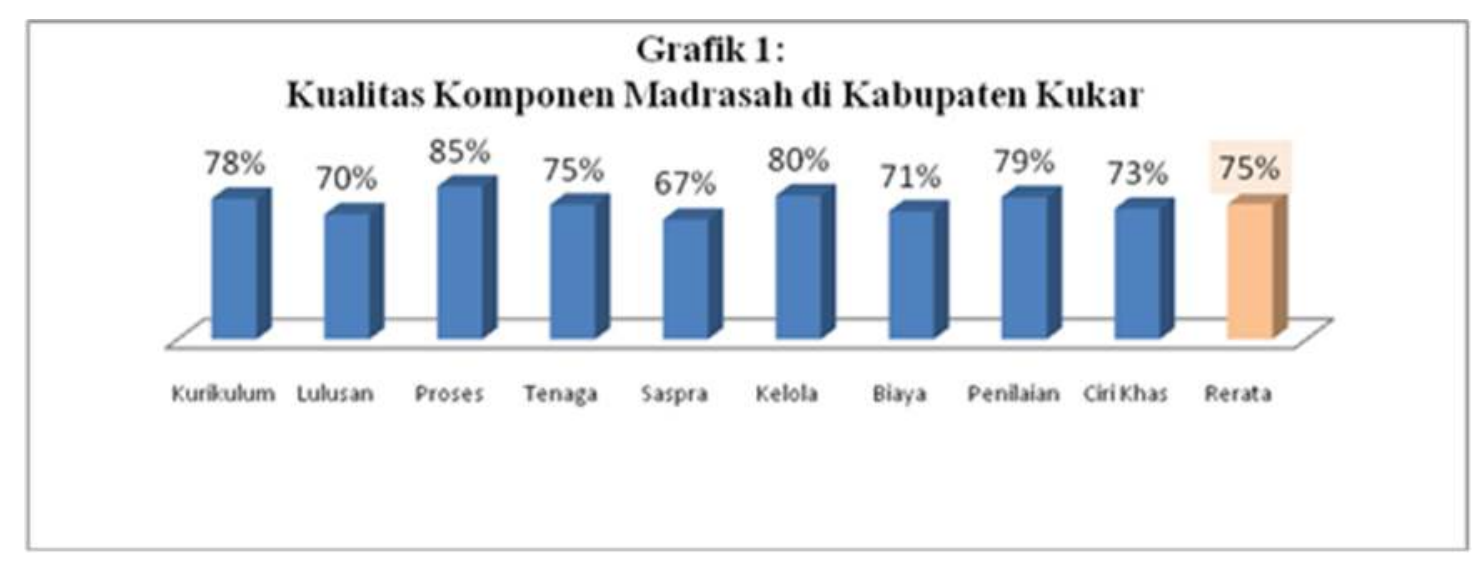

Keterangan:

$0-20$

$21-40$

$41-60$

$61-80$

$81-100$
$=$ Sangat Rendah

$=$ Rendah

$=$ Sedang

$=$ Tinggi

$=$ Sangat Tinggi
Jika mengamati pada grafik 1 menunjukkan bahwa "Standar Proses Pendidikan" yang memiliki tingkat pencapaian kualitas tertinggi yaitu $85 \%$ (terkategori sangat tinggi) mendekati standar nasional pendidikan. 
Kemudian standar pengelolaan berada pada peringkat kedua dengan pencapaian kualitas $80 \%$ (sangat tinggi) dari standar nasional pendidikan. Disusul standar penilaian dan standar kurikulum. Sedangkan standar yang terendah persentase pencapaian kualitasnya adalah "Standar Sarana dan Prasarana" dengan persentase $64 \%$ (tinggi).

Berikut ini akan dipaparkan capaian kualitas madrasah aliyah di Kabupaten Kutai Kartanegara berdasarkan Peraturan Pemerintah Nomor 19 Tahun 2005 tentang delapan (8) Standar Nasional Pendidikan sebagai berikut:

\section{Kualitas Standar Isi (Kurikulum)}

Instrumen standar Isi (Kurikulum) ini terdiri dari 14 item pertanyaan Disusun berdasarkan Lampiran Peraturan Menteri Pendidikan Nasional Nomor 22 Tahun 2006 Tanggal 23 Mei 2006 Standar Isi. Cakupannya terdiri atas: Kurikulum yang diterapkan, Struktur kurikulum, Pelaksanaan kurikulum, Esktrakurikuler, Pengembangan diri, Standar Isi dan Kompetensi Dasar, Silabus, Perangkat pembelajaran, dan Kalender pendidikan.

Capaian kualitas standar isi (kurikulum) terhadap 16 madrasah aliyah di Kabupaten Kutai Kartanegara terkategori tinggi dengan rerata persentase $78 \%$. Terdapat 8 madrasah yang memiliki capaian kualitas diatas 80 sd 95\% Yaitu, MAN Kota Kota Bangun, MAN Tenggarong, MAS Al-Masyuriyah masingmasing (82\%), MAS Nuruddin, MAS DDI Karya Baru masing-masing (84\%), MAS Nahdatul Wathan (88\%), MAS PPKP Ribathul KhaiL (89), MAS Ibadurrahman (93), dan MAS Miftahul Ulum Anggana yang memiliki capaian kualitas tertinggi dengan persentase $95 \%$ mendekatai standar nasional pendidikan. Namun, masih terdapat 4 madrasah belum maksimal pencapaian kualitas standar isinya. Keempat madrasah yang dimaksud adalah MAS Al-Mu'minun, MAS Darul Ihsan, MAS Al-Mukarramah, dan MAS AlIkhsan.

Ada beberapa aspek-aspek yang belum dimaksimalkan pencapaian kualitasnya meliputi : a) Pengembangan
Kurikulum tidak melibatkan beberapa unsur terkait dan belum memenuhi unsurunsur mekanisme penyusunan KTSP karena penyusunannya hanya melalui tahap rapat dewan guru tanpa melibatkan unsur lainnya seperti komite madrasah, konselor, dan penyelenggara lembaga pendidikan, b) Penyusunan kurikulum muatan lokal yang hanya melibatkan guru, Pemilihan program pengembangan diri dalam bentuk kegiatan konseling dan kegiatan ekstrakurikuler yang hanya melaksanakan dua jenis program ekstrakurikuler. Pada hakikatnya Penyusunan kurikulum muatan lokal sejatinya melibatkan seluruh komponen yang dipersyaratkan dengan melibatkan guru, komite madrasah, dinas pendidikan, penyelenggara pendidikan, dan instansi terkait di daerah. c) Pengembangan KTSP hanya mampu mengembangkan 1 sampai 4 silabus mata pelajaran sehingga dalam pengembangan KTSP hanya sebanyak 1\% $25 \%$ guru menyusun silabus sendiri, d) Madrasah hanya melaksanakan kurikulum berdasarkan prinsip perbaikan layanan pembelajaran saja, tanpa melaksanakan pengayaan layanan pembelajaran, pendayagunaan kondisi alam sosial dan budaya. Belum sepenuhnya madrasah memiliki program pengembangan diri dalam bentuk kegiatan konseling dan kegiatan ekstrakurikuler, e) Rata- rata guru pelajaran dalam merancang tugas mandiri tidak terstruktur untuk mencapai kompetensi tertentu dengan capaian hanya $50 \%$. Masih terdapat guru yang belum mampu merancang tugas mandiri terstruktur untuk mencapai kompetensi tertentu

\section{Kualitas Standar Kompetensi Lulusan}

Instrumen Standar Kompetensi Lulusan terdiri dari 27 item pertanyaan disusun berdasarkan Lampiran Peraturan Menteri Pendidikan Nasional Nomor 23 Tahun 2006 Tanggal 23 Mei 2006 tentang Standar Kompetensi Lulusan (SKL). Cakupannya terdiri atas: Kemampuan berpikir, Kemampuan menganalisis, 
Pengalaman belajar dan keterampilan berbahasa.

Capaian kualitas standar kompetensi lulusan (SKL) terhadap 16 madrasah aliyah di Kabupaten Kutai Kartanegara terkategori tinggi dengan rerata persentase $70 \%$. Ada 5 madrasah yang memiliki capaian kualitas terkategori sangat tinggi standar kompetensi lulusannya yaitu; MAN Kota Bangun (89\%), MAN Tenggarong (93\%), MAS Miftahul Ulum (99\%), MAS Ibadurrahman (81\%), dan MAS PPKP Ribathul Khail $(83 \%)$.

Standar kompetensi lulusan yang dimiliki oleh MAS Al-Mu'minun dan MAS Al-Mukarramah masih pada kategori sedang dengan persentase antara $52-56 \%$. Terdapat pula 2 madrasah yang memiliki pencapaian kualitas standar kompetensi lulusan terkategori rendah dengan persentase dibawah $35 \%$ saja, dan madrasah yang dimaksud adalah MAS AlIkhsan dan MAS Nahdathul Wathan.

Hal yang dianggap belum maksimal dan masih perlu mendapat perhatian dalam meningkatkan kualitas lulusannya antara lain: a) Rendahnya pencapaian kualitas yang dimiliki di dominasi pada lemahnya Kemampuan berpikir, Kemampuan menganalisis, Pengalaman belajar dan keterampilan berbahasa. Belum maksimalnya pengalaman belajar siswa dalam hal pembelajaran terkait analisis dan pemecahan masalah-masalah kompleks, b) Pembelajaran yang melibatkan siswa dalam memahami kelompok mata pelajaran Iptek secara efektif. Aspek kemampuan belajar untuk menunjukkan kemampuan berpikir logis, kritis, kreatif, dan inovatif dalam pengambilan keputusan hanya mencapai ketuntasan belajar mata pelajaran kelompok IPTEK ditetapkan antara 65 sampai 69,9, c) Peserta didik belum memiliki pengalaman belajar pada aspek analisis dan pemecahan masalah-masalah kompleks, menumbuhkan pembiasaan peserta didik mencari pengetahuan dari berbagai sumber belajar, pemanfaatan lingkungan secara produktif dan bertanggung jawab, serta kemampuan peserta didik mengekspresikan diri melalui kegiatan seni dan budaya.

\section{Kualitas Standar Proses Pendidikan}

Instrumen Standar Proses

Pendidikan terdiri dari 10 item pertanyaan disusun berdasarkan Lampiran Peraturan Menteri Pendidikan Nasional Nomor 41 Tahun 2007 Tanggal 23 November 2007 tentang Standar Proses Pendidikan. Cakupannya terdiri atas: Pengembangan silabus, Penyusunan RPP, Proses pembelajaran, Pemantauan, supervisi dan evaluasi pembelajaran.

Walaupun secara umum pencapaian kualitas standar proses pendidikan terhadap 16 madrasah aliyah di Kabupaten Kutai Kartanegara terkategori sangat tinggi dengan tingkat persentase $85 \%$ mendekati Standar Nasional Pendidikan, namun terdapat beberapa madrasah yang pencapaian kualitasnya masih di terkategori sedang ke tinggi seperti pada MAS Darul Ihsan dengan kategori sedang, dan MAS As'adiyah, MAS Bahrul Ulum, MAS Al-Mukarramah.

Ada dua hal yang perlu memperoleh dukungan jika ingin meningkatkan kualitas standar proses pendidikan yaitu: a) Dalam pengembangan silabus belum sepenuhnya dilakukan secara mandiri, dominan pengembangan silabus tersebut dengan mengadopsi contoh yang sudah ada, b) Kepala Madrasah dalam melakukan supervisi pembelajaran dominan hanya melakukan supervisi melalui 2 aspek saja. Padahal dalam melakukan supervisi pembelajaran ada 4 cara yaitu: pemberian contoh, diskusi, pelatihan, konsultasi.

\section{Kualitas Standar Pendidik dan Tenaga Kependidikan}

Mengukur kualitas standar pendidik dan tenaga kependidikan ada 18 item instrumen pertanyaan disadur berdasarkan Peraturan Menteri Pendidikan Nasional Nomor 16 Tahun 2007 Tanggal 4 Mei 2007 Tentang Standar Kualifikasi 
Akademik dan Kompetensi Guru, serta Peraturan Menteri Pendidikan Nasional Nomor 13 Tahun 2007 Tanggal 17 April 2007 Tentang Standar Kepala Sekolah/Madrasah. Cakupannya terdiri atas: Kualifikasi dan kompetensi guru, Kualifikasi dan kompetensi kepala sekolah/madrasah, serta kualifikasi tenaga administrasi, perpustakaan, dan laboratorium.

Berdasarkan hasil analisis, ternyata terdapat empat (4) madrasah yang masih memiliki kualitas pendidik dan tenaga kependidikan terkategori sedang dengan persentase dibawah 55\%. Madrasah yang dimaksud adalah; MAS Al-Mu'minun, MAS Hidayatul Mubtadin (50\%), MAS Bahrul Ulum (53\%), dan MAS Darul Ihsan $(56 \%)$.

Beberapa madrasah di Kabupaten Kutai Kartanegara memiliki kualitas yang rendah, hal ini dipengaruhi oleh beberapa hal yaitu: Pendidik belum sepenuhnya memiliki kualifikasi minimum sarjana (S1) atau diploma IV. Masih terdapat pendidik mengajar tidak sesuai dengan latar belakang kependidikannya. Kualifikasi dan latar belakang pendidikan yang dimiliki oleh tenaga administrasi yang masih minim dan tidak sesuai dengan tugasnya. Kurangnya tenaga perpustakaan dan tenaga laboratorium yang dimiliki serta tidak sesuai dengan kualifikasinya. Manajemen pembelajaran belum dijalankan sesuai dengan prinsip-prinsip pembelajaran oleh sebagian pendidik, seperti perencanaan, pelaksanaan, dan pengevaluasian pembelajaran

Ketersediaan pendidik dan tenaga kependidikan masih kurang olehnya itu terdapat beberapa pendidik mengampuh mata pelajaran lebih dari satu sehingga berdampak pada kompetensi pendidik yang mengajar pasti sudah tidak sesuai dengan latar belakang kependidikannya. Begitu pula kondisi tenaga administrasi seperti tenaga perpustakaan dan tenaga laboratorium tetap belum memadai baik dari aspek kuantitas maupun kompetensi.

\section{Kualitas Standar Sarana dan Prasarana}

Instrumen Standar Sarana dan

Prasarana terdiri dari 46 item pertanyaan Disusun berdasarkan Peraturan Menteri Pendidikan Nasional Nomor 24 Tahun 2007 Tanggal 28 Juni 2007 Tentang Standar Sarana dan Prasarana. Cakupannya terdiri atas: Lahan Madrasah, Bangunan madrasah, Pemeliharaan bangunan madrasah, Kelengkapan prasarana, Kondisi sarana dan prasarana.

Kualitas standar sarana dan prasarana yang dimiliki oleh madrasah aliyah di Kabupaten Kutai Kartanegara tingkat pencapaiannya baru $67 \%$, masih terdapat 33\% fasilitas sarana dan prasarana yang belum terpenuhi di hampir seluruh madrasah di Kabupaten Kutai Kartanegara.

MAS As'adiyah Santan Tengah dan MAS Bahrul Ulum Kenohan memiliki capaian kualitas standar sarana dan prasarana dengan kategori rendah dengan persentase $31 \%$ saja.

Kualitas standar sarana dan prasarana yang dimiliki oleh madrasah memang masih jauh dari harapan. Ada beberapa hal yang perlu yang mendesak untuk di benahi agar dapat mendongkrak pencapaian kualitasnya, seperti:

a. Kelengkapan Laboratorium masih kurang (Biologi, fisika, Kimia, Komputer, dan Bahasa)

b. Ketersediaan ruangan Konseling dan ruangan UKS belum lengkap bahkan terdapat beberapa madrasah yang tidak memiliki ruangan tersebut.

c. Kondisi sarana dan prasarana yang dimiliki oleh madrasah dibawah standar

\section{Kualitas Standar Pengelolaan}

Instrumen Standar Pengelolaan terdiri dari 20 item pertanyaan, disusun berdasarkan Peraturan Menteri Pendidikan Nasional Nomor 19 Tahun 2007 Tanggal 23 Mei 2007 tentang Standar Pengelolaan Pendidikan Oleh Satuan Pendidikan Dasar dan Menengah. Cakupannya terdiri atas: Visi, misi, tujuan Satuan Pendidikan, dan rencana kerja Satuan Pendidikan, Struktur organisasi, Pelaksanaan rencana kerja, 
Evaluasi diri, dan Sistem informasi manajemen.

Meskipun pencapaian kualitas pengelolaan tinggi, namun masih terdapat madrasah yang memiliki kualitas standar pengelolaan yang terkategori sedang seperti yang dialami oleh MAS PPKP Ribathul Khail dengan persentase 58\%.

Kualitas standar pengelolaan yang dimiliki oleh madrasah aliyah di Kabupaten Kutai Kartanegara tingkat pencapaiannya $80 \%$, artinya masih terdapat $20 \%$ kualitas pengelolaan yang belum dimaksimalkan.

Walaupun Kualitas pengelolaan madrasah sudah dianggap bagus, namun terdapat beberapa komponen yang perlu di tingkatkan pengelolaan seperti:

a. Madrasah belum memaksimalkan pelibatan masyarakat dan membangun kemitraan dengan lembaga lain dalam bentuk Mou dibidang pengelolaan pendidikan,

b. Program pengawasan belum dimaksimalkan oleh madrasah dalam bentuk sosialisasi kepada pendidik dan tenaga Kependidikan.

\section{Kualitas Standar Pembiayaan}

Instrumen Standar Pembiayaan terdiri dari 24 item pertanyaan, disusun berdasarkan Peraturan Menteri Pendidikan Nasional Nomor 69 Tahun 2009 Tentang Standar Biaya Operasional Pendidikan. Cakupannya terdiri atas: Dokumen nilai aset sarana dan prasarana, Pembiayaan pendidik dan tenaga kependidikan, Pembiayaaan kebutuhan pendidikan, Pembayaran gaji, insentif, transport, dan tunjangan lain bagi guru dan tenaga administrasi, Pembiayaan menunjang pelaksanaan kegiatan pembelajaran, dan Pembiayaan berbagai jenis kegiatan madrasah.

Meskipun pencapaian kualitas pembiayaan terkategori tinggi, namun dominan madrasah masih memiliki kualitas standar pembiayaan yang belum mengimplementasikan seluruh item yang dijadikan indikator pembiayaan.
Ada beberapa madrasah yang perlu ditingkatkan kualitas standar pembiayaannya seperti MAS Al-Ikhsan, MAS Hidayatul Mubtadin, MAS AlMu'minun, MAS Bahrul Ulum, MAS AlMasyuriyah, dan Al-Mukarramah, karena memiliki capaian kualitas pembiayaan yang rendah di banding dengan madrasah lainnya.

Indikator yang menjadikan madrasah tersebut memiliki kualitas rendah pada standar pembiayaan meliputi aspek; Pembiayaan pendidik dan tenaga kependidikan, Pembiayaaan kebutuhan pendidikan, Pembayaran gaji, insentif, transport, dan tunjangan lain bagi guru dan tenaga administrasi, Pembiayaan menunjang pelaksanaan kegiatan pembelajaran, dan Pembiayaan berbagai jenis kegiatan madrasah.

Standar pembiayaan madrasah juga termasuk salah satu yang memiliki kualitas yang terendah setelah standar sarana dan prasarana. Oleh karena itu, ada beberapa hal yang perlu diperhatikan untuk meningkatkan kualitasnya diantaranya:

a. Madrasah mengalokasikan dana untuk kegiatan kesiswaan. Kegiatan kesiswaan yang dibiayai sekolah/madrasah antara lain: kegiatan pramuka, kerohanian, olahraga, UKS/M, OSIS/M, LKIR dan lain sebagainya

b. Madrasah menyediakan biaya pengadaan daya dan jasa. Biaya pengadaan daya dan jasa misalnya: listrik, telepon, dan air.

c. Madrasah melakukan bantuan subsidi silang kepada siswa yang kurang mampu secara ekonomi, baik melalui pengurangan dan pembebasan biaya pendidikan (SPP), pemberian beasiswa dan sebagainya untuk membantu siswa dari keluarga kurang mampu agar dapat mengikuti pendidikan secara teratur dan berkelanjutan

d. Madrasah menyediakan biaya pengadaan kegiatan rapat seperti; rapat penerimaan siswa baru, rapat evaluasi semester siswa, rapat kenaikan kelas, 
rapat kelulusan, rapat pemecahan masalah, rapat koordinasi, rapat wali murid, dan sebagainya.

\section{Kualitas Madrasah Aliyah Berdasarkan Tipologi Madrasah}

Penelitian ini memberikan pengelompokan berdasarkan tipologi madrasah yang di bagi menjadi tiga (3) tipologi yaitu; 1) Madasah Aliyah Negeri (MAN) yang dikelola oleh pemerintah sebanyak 2 madrasah, 2) MAS Non Pesantren yang dikelola oleh yayasan sebanyak 9 madrasah, dan 3) MAS Pesantren yang di bina oleh pondok pesantren sebanyak 5 madrasah.

Berdasarkan hasil analisis tabulasi frekuensi terhadap 16 madrasah yang dijadikan objek penyebaran kuesioner dalam penelitian ini menunjukkan bahwa kualitas madrasah yang dengan tipologi MAN yang dikelola langsung oleh pemerintah masih memiliki kualitas yang lebih bagus terkategori "sangat tinggi" dengan persentase $86 \%$ mendekati standar nasional pendidikan. sedangkan MAS yang di naungi oleh pondok pesantren sedikit lebih bagus kualitasnya dibanding dengan MAS Non Pesantren yang dikelola oleh Yayasan. Sebagaimana dapat di lihat pada grafik 2 berikut ini:

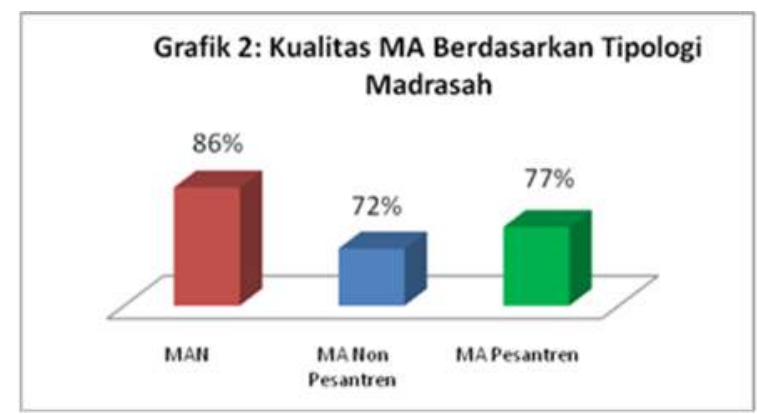

\section{Kualitas MAN di Kabupaten Kutai Kartanegara}

Persebaran Madrasah Aliyah Negeri (MAN) Kabupaten Kutai Kartanegara Provinsi Kalimantan Timur tidaklah merata hanya memiliki 2 madrasah yang tersebar pada dua (2) Kecamatan saja, yaitu MAN Kota Bangun di Kecamatan Kota Bangun, dan MAN Tenggarong di Kecamatan Tenggarong.

Berdasarkan hasil analisis tabulasi data kuesioner terhadap 2 MAN yang dikelola oleh pemerintah menunjuk pencapaian kualitas terhadap 8 komponen standar nasional pendidikan secara umum untuk ke dua MAN tersebut terkategori "Sangat Tinggi" mendekati standar nasional pendidikan dengan persentase antara 82 s/d 88\%. Namun, jika diperbandingkan kedua MAN tersebut, maka MAN Tenggarong masih diatas pencapaian kualitas madrasahnya di banding MAN Kota Bangun. Jika dilihat dari grafis kecenderungan kualitas madrasah seperti terlihat pada grafik 3 dibawah ini:

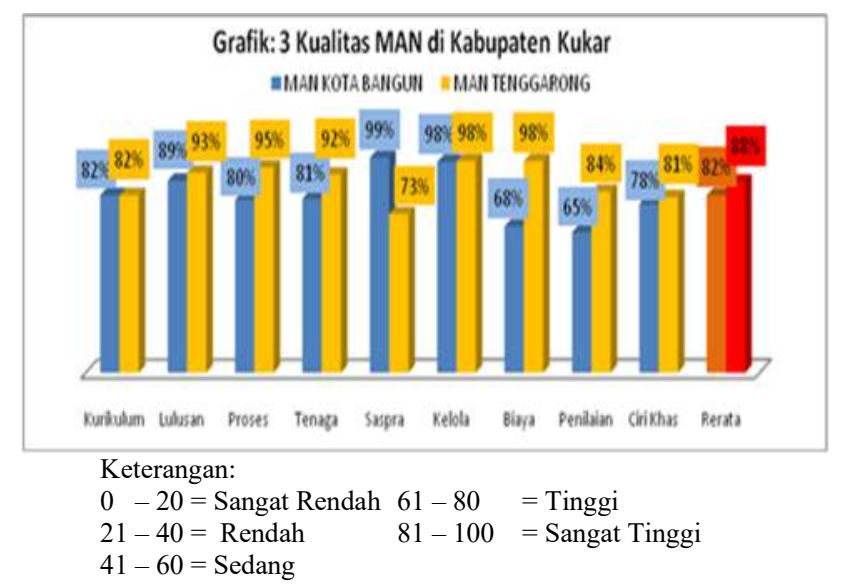

Hal yang memengaruhi tingkat ketercapaian kualitasnya dapat dilihat pada kualitas standar sarana dan prasarana, kualitas standar penilaian serta standar kualitas standar pembiayaan madrasah.

Kualitas Standar sarana dan prasarana yang dimiliki oleh MAN Kota Bangun dengan persentase $68 \%$. Kondisi ini masih memiliki beberapa kekurangan seperti ketersediaan ruangan laboratorium Biologi dan Fisika sampai saat ini belum ada. Begitu pula ruangan perpustakaan tidak sesuai dengan kapasitas dan koleksi buku yang dimiliki belum lengkap. Kondisi Ruangan Konseling bagi guru BK masih darurat sehingga guru Bimbingan Konseling yang melakukan pembimbingan kepada siswa harus menempati ruangan guru yang suasananya pasti ramai sehingga 
dalam melakukan pembinaan tidak terlalu maksimal hasilnya. Kapasitas ruangan belajar yang di miliki oleh MAN Kota Bangun sudah sesuai dengan yang dipersyaratkan, namun sarana pendukungnya belum lengkap seperti belum memadainya jumlah dan kondisi meja belajar, lemari, dan pendingin ruangan masih jauh dari standar.

Kualitas Standar Penilaian yang dimiliki oleh MAN Kota Bangun persentasenya $65 \%$ terkategori tinggi, namun masih terdapat beberapa item yang dianggap belum maksimal pelaksanaannya seperti: 1) Tingkat pencapaian pembuatan silabus dengan indikator pencapaian $\mathrm{KD}$ dan teknik Penilaian dilakukan secara lengkap oleh guru, namun hanya mencapai antara $26-50 \%$, ini dianggap ketercapaiannya kurang efektif, hal ini ditengarai karena keterbatasan bahan referensi buku. 2) Proses penilaian pembelajaran diresponi oleh guru berkisar antara $26-50 \%$ guru yang melakukan penilaian pembelajaran terkait dengan pengembangan instrumen/pedoman penilaian, teknik penilaian tes, pengamatan dan penugasan, serta pengolahan hasil penilaian formatif. 3) Dalam penentuan hasil akhir seharusnya dewan guru melakukan rapat dengan mempertimbangkan hasil penilaian oleh guru. Namun kenyataannya MAN Kota Bangun langsung menentukan nilai yang diberikan oleh guru tanpa dirapatkan oleh dewan guru. 4) Lambatnya penerbitan dan penyerahan ijazah kepada siswa yang telah lulus.

Begitu pula pada pencapaian Kualitas Standar Pembiayaan pada MAN Tenggarong mendekati standar nasional pendidikan dengan persentase $98 \%$ (terkategori sangat tinggi), sedangkan MAN Kota Bangun hanya 65\% (terkategori tinggi). Ada beberapa item standar pembiayaan yang belum di maksimalkan di MAN Kota Bangun diantaranya: 1) Belum dimaksimalkan dana transport dan tunjangan lain pada tahun berjalan kepada bagi guru dan tenaga administrasi, karena gaji guru, tunjangan kinerja bagi PNS sudah masuk dalam DIPA. Begitu pula telah menerima insentif dari pemerintah daerah (Pemda). 2) Tidak adanya dana yang dikelola dari masyarakat dalam bentuk sumbangan pendidikan sehingga berpengaruh kesejahteraan dan peningkatan mutu pendidikan. 3) Tidak melaksanakan subsidi silang utuk membantu siswa kurang mampu. 4) Pungutan dana dari masyarakat tidak dilakukan lagi oleh karena itu pelibatan berbagai pihak (Stakeholder) untuk pengambilan keputusan dalam penetapan dana dari masyarakat sebagai biaya operasional madrasah tidak dilakukan lagi

\section{Kualitas MAS Non Pesantren di Kabupaten Kutai Kartanegara}

Tipologi Madrasah Aliyah Swasta Non Pesantren yang dikelola oleh Yayasan di Kabupaten Kutai Kartanegara berjumlah Sembilan (9) yang tersebar pada 8 kecamatan. Persebaran tipologi madrasah ini tidak merata karena ada 10 kecamatan yang belum dikelola oleh yayasan. Wilayah persebaran madrasah tersebut meliputi; 1) Kecamatan Loa Janan (MAS DDI Karya Baru, akreditasi B), 2) Kecamatan Samboja (MAS Nuruddin, akreditasi A), 3) Kecamatan Anggana (MAS Miftahul Ulum, Akreditasi A, dan MAS Darul Ihsan, akreditasi B), 4) Kecamatan Marang Kayu (MAS As'adiyah, akreditasi B), 5) Kecamatan Kenohan (MAS Bahrul Ulum, akreditasi B), 6) Kecamatan Muara Jawa (MAS Al-Mukarramah, akreditasi B), 7) Kecamatan Muara Kaman (MAS Hidayatul Mubtadin, akreditasi B), 8) Kecamatan Tenggarong Seberang (MAS Al-Ikhsan, akreditasi B). Pada grafik 4 dapat kita mengamati persentase kualitas MAS Non Pesantren di kabupaten Kutai kartanegara sebagai berikut: 


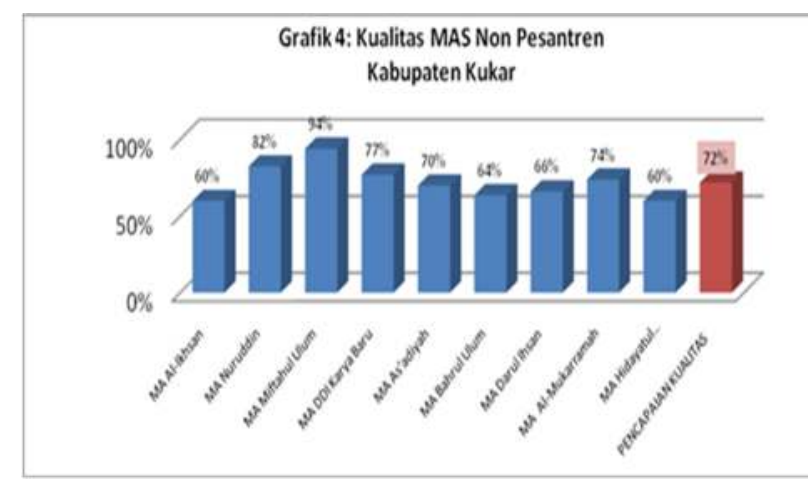

Berdasarkan hasil analisis tabulasi pada grafik 4 tersebut menunjukkan bahwa pencapaian tingkat kualitas MAS Non Pesantren yang dikelola oleh Yayasan yang berjumlah 9 madrasah yang tersebar pada 8 Kabupaten terkategori "Tinggi" yaitu $72 \%$. Madrasah yang dianggap rendah pencapaian kualitasnya terdapat di MAS Al-Ikhsan Tenggarong Seberang, dan MAS Hidayatul Mubtadin dengan persentasi $60 \%$. Sedangkan MAS Non Pesantren yang memiliki pencapaian kualitas tertinggi yaitu MAS Miftahul Ulum 94\% (terkategori sangat tinggi), dan MAS Nuruddin $82 \%$ (terkategori sangat tinggi).

Jika dilihat kualitas MAS Non pesantren yang dikelola oleh yayasan berdasarkan delapan (8) komponen Standar Nasional Pendidikan (SNP), menunjukkan bahwa secara umum persentase pencapaian kualitas terkategori tinggi (72\%) mendekati standar nasional pendidikan. Dari 8 komponen standar yang dijadikan tolok ukur tersebut, yang paling tinggi pencapaian kualitasnya adalah "Standar Proses Pendidikan" dengan kisaran $82 \%$ (terkategori tinggi), dan "Standar Sarana dan Prasarana" yang memiliki pencapaian kualitas yang terendah dengan kisaran 63\% (terkategori tinggi). Selanjutnya dapat diamati pada grafik 5 berikut ini.

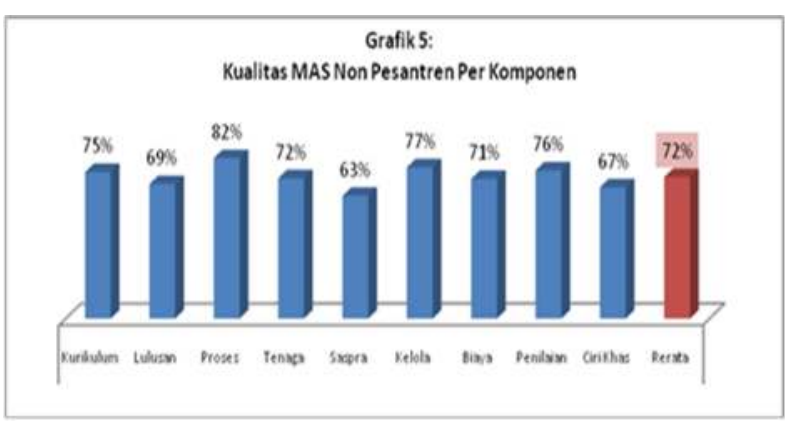

\section{Kualitas MAS Pesantren di Kabupaten Kutai Kartanegara}

MAS Pesantren yang dikelola oleh Pondok Pesantren di Kabupaten Kutai Timur berjumlah 5 madrasah yang tersebar pada 3 kecamatan yaitu MAS AlMu'minum (Kecamatan Muara Muntai), MAS Al-Masyuriyah, MAS Ibadurrahman, MAS Nahdathul Watan (Kecamatan Tenggarong Seberang) MAS PPKP Ribathul Khail (Kecamatan Tenggarong), ini berarti bahwa persebaran madrasah yang dikelola oleh pondok pesantren tidaklah merata.

Berdasarkan hasil analisis tabulasi terhadap 5 madrasah yang tersebar pada 3 kecamatan tersebut, menunjukkan bahwa secara umum pencapaian tingkat kualitasnya terkategori "Tinggi" yaitu 77\% (terkategori tinggi). Sedangkan jika dianalisis per madrasah maka MAS Ibadurrahman yang memiliki pencapaian kualitas terhadap 8 standar nasional pendidikan yang lebih bagus dibanding dengan madrasah lainnya dengan tingkat persentase $87 \%$ (terkategori sangat tinggi) mendekati standar nasional pendidikan. Dan MAS Al-Mu'mium yang terletak di Kecamatan Muara Muntai yang memiliki pencapaian kualitas yang paling rendah dengan persentase $68 \%$. Dapat diamati pada grafik berikut ini: 


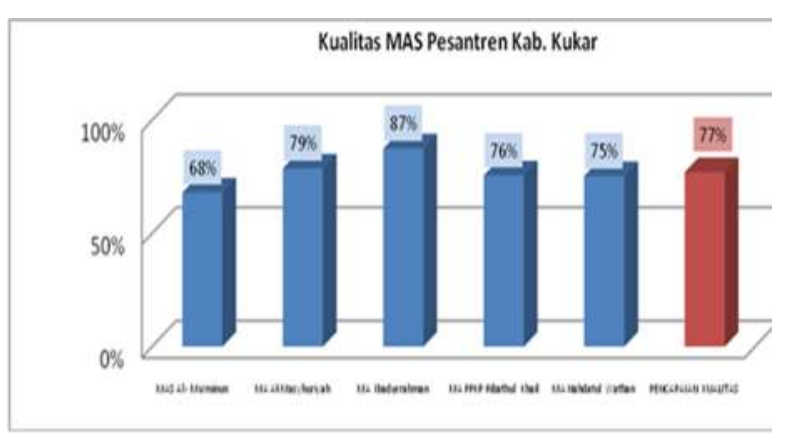

Pencapaian kualitas MAS Pesantren jika diamati berdasarkan 8 komponen Standar Nasional Pendidikan, dan berdasarkan hasil analisis frekuensi tabulasi menunjukkan bahwa terdapat 3 komponen standar yang terkategori sangat tinggi mendekati standar nasional pendidikan yaitu standar proses pendidikan (90\%), standar penilaian (88), dan standar isi/kurikulum (83\%). Sedangkan 5 komponen standar lainnya memiliki pencapaian kualitas terkategori tinggi, namun yang paling rendah pencapaian kualitasnya adalah standar kompetensi lulusan (63\%). Untuk lebih jelasnya dapat diamati pada grafik berikut ini:

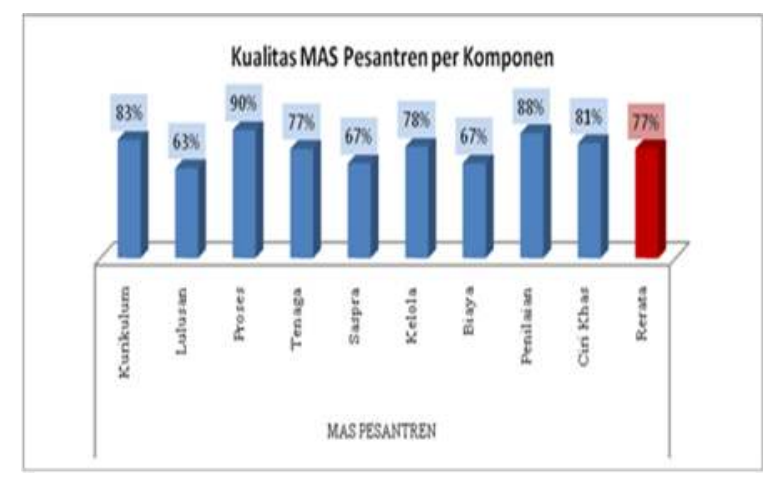

\section{PENUTUP}

Berdasarkan paparan hasil temuan penelitian terhadap kualitas Madrasah Aliyah di Kabupaten Kutai Kartanegara, maka dapat disimpulkan sebagai berikut:

Secara keseluruhan pencapaian kualitas terhadap 16 Madrasah Aliyah di Kabupaten Kutai Kartanegara yang didasarkan pada 8 standar pendidikan nasional terkategori "tinggi" dengan rerata persentase $75 \%$ dari Standar Nasional Pendidikan.
Standar Proses Pendidikan memiliki pencapaian kualitas mendekati standar nasional pendidikan dengan rerata persentase $85 \%$ (terkategori sangat tinggi). Sedangkan standar Sarana dan Prasarana yang paling rendah pencapaian kualitasnya dengan rerata persentase $67 \%$ (terkategori tinggi).

Madrasah Aliyah Negeri (MAN) masih memiliki Pencapaian Kualitas yang lebih baik dari Madrasah Aliyah Swasta (MAS) baik yang dikelola oleh yayasan maupun yang ditangani oleh pondok pesantren. Sedangkan MAS yang di naungi oleh pondok pesantren sedikit lebih baik pencapaian kualitasnya dibanding dengan MAS Non Pesantren yang dikelola oleh Yayasan.

\section{UCAPAN TERIMA KASIH}

Pertama-tama penulis mengucapan terima kasih kepada bapak Kepala Balai Penelitian dan Pengembangan Agama Makassar, telah memberikan kepercayaan kepada penulis untuk ikut terlibat dalam melakukan penelitian ini di Kabupaten Kutai Kartanegara. Ucapan terima kasih juga penulis haturkan kepada Kepala Kantor Kementerian Agama Kabupaten Kutai Kartanegara bersama seluruh jajarannya yang telah memfasilitasi dan mendampingi peneliti dalam pengumpulan data. Tak lupa pula penulis mengucapkan terima kasih kepada segenap kepala madrasah, wakil kepala madrasah, para tenaga pendidik dan kependidikan di madrasah aliyah negeri maupun swasta atas kesediaannya menerima dan mengisi angket yang telah peneliti edarkan di madrasah masing-masing. Kepada TIM Pengelola Jurnal Educandum penulis juga menyampaikan terima kasih telah berkenan memuat tulisan ini.

\section{DAFTAR PUSTAKA}

Departemen Pendidikan Nasional Republik Indonesia, Peraturan Pemerintah 
Republik Indonesia Nomor 19 Tahun 2005 tentang Standar Nasional Pendidikan, (Jakarta: 2005), hlm. 3

Gatot Harmanto. 1700 Bank Soal Bimbingan Pemantapan Geografi untuk SMA/MA: Ringkasan Materi $X, X I$, dan XII. Bandung: Yrama Widya.Gatot Harmanto. 2008

Lampiran I Keputusan Menteri Agama Republik Indonesia Nomor 39 Tahun 2015. Tentang Rencana Strategis Kementerian Agama Tahun 2015-2019.

Lampiran Peraturan Menteri Pendidikan Nasional Nomor 22 Tahun 2006 Tanggal 23 Mei 2006 Standar Isi

Misi Kementerian Agama periode Pembangunan 2014 - 2019

Nurlaesa,Hi.Jamaludin. "Upaya Peningkat an Mutu Guru' 'http://nurlaesahijam aludin.blogspot.co.id/

Peraturan Menteri Pendidikan Nasional Republik Indonesia nomor 24 tahun 2008. tentang Standar Tenaga Administrasi Sekolah/Madrasah

Peraturan Menteri Pendidikan Nasional Republik Indonesia nomor 25 tahun 2008. tentang Standar Tenaga Perpustakaan Sekolah/Madrasah

Peraturan pemerintah republik Indonesia nomor 19 tahun 2005 tentang Standar Nasional Pendidikan

Priadi Surya. Disertasi. Pemetaan Pendidikan (Education Mapping) Sebagai Dasar Meningkatkan Layanan Pendidikan. Universitas Negeri Yogyakarta (Priadisurya@Uny.Ac.Id)

Rencana Strategis (Renstra) Kementerian Agama Tahun 2015 - 2019,

Riat Nugroho D, Kebijakan Publik untuk Negara-Negara Berkembang, Model-Model Perumusan, Implementasi dan Evaluasi,(Jakarta: Pt Alex Media Komputindo Gramedia, 2006)

Sarjilah, "Makna Pengembangan Manusia pada Pelatihan Guru", http://ipmpjogja.diknas.go.id./mater i/wi/sarjilah/karyatulismaknapmtak ehom.pdf,hlm.2

Situs Kementerian Agama RI : http://pendis.kemenag.go.id/index.p $\mathrm{hp}$ ? $\mathrm{a}=\operatorname{artikel} \& \mathrm{id} 2=$ prioritas 2013 .

Situs Kementerian Agama RI : http://pendis.kemenag.go.id/index.p $\mathrm{hp} ? \mathrm{a}=\operatorname{artikel} \& \mathrm{id} 2=$ prioritas 2014

Subhan, Arief. 2012. Lembaga Pendidikan Islam Indonesia Abad ke-20; pergumulan Antara Modernisasi dan Identitas. Jakarta: Prenada Media Group.

Undang-undang RI No. 20 Tahun 2003 tentang Sistem Pendidikan Nasional, (Bandung: Citra Umbara, 2003), hlm. 27. 